\title{
Evaluation of the neurobehavioural and Histo- architecture changes of the hippocampus and pancreas of the streptozotocin-induced diabetic male wistar rats responding to $Z$. Officinale extract
}

\author{
Godam Elvis Tams ${ }^{1 *}$, Atumen Superior Tejiri ${ }^{1}$, Owolagba GK ${ }^{2}$ and Ujah WO ${ }^{1}$ \\ ${ }^{1}$ Department of Human Anatomy, College of Health Sciences, Bingham University Karu Nasarawa State, Nigeria \\ ${ }^{2}$ Department of Medical Laboratory Science, Usman Dan Fodio University, Sokoto, Nigeria
}

\begin{abstract}
This study aimed to evaluate the histological; biochemical and neurobehavioral effects of ethanolic extract of Zingiber officinale in streptozotocin (STZ) induced diabetic male Wistar rats. Twenty-five male rats were used in this study. Streptozotocin was used to induce Diabetes mellitus with a single IP injection of $55 \mathrm{mg} /$ $\mathrm{kg}$ bw. Sustained hyperglycaemia of $200 \mathrm{mg} / \mathrm{dl}$ and above was considered diabetic. The animals were further divided into the following groups: Group A; Normal Control, Group B; Diabetic Control; Group C; (Diabetic+Zingiber officinale (200 mg/kg bw) for 14 days), Group D; (Diabetic + Zingiber officinale (200 mg/kg bw) for 21 days) and Group E; (Diabetic+Metformin $(500 \mathrm{mg} / \mathrm{kg}$ bw)) orally for 21 days. The behavioral study was done as grouped using the elevated plus maze (EPM) Model. After the last day of treatment, the rats were sacrificed and blood samples collected were assayed spectrophotometrically for serum concentration of liver enzymes, intracellular antioxidants Superoxide dismutase (SOD), Glutathione peroxidase (GPx) and Malondialdehyde (MDA). The brain (hippocampus), and Pancreas were carefully excised fixed, and processed for histological examination. The result showed significantly increase in antioxidants and reduction for Malondialdehyde in Z. officinale treated groups (C \&D) compared with diabetic control and metformin-treated groups, (B \&E). Z. officinale treated groups (C \&D) showed repair of neuronal cells injury caused by neuropathy. There was significant cognitive improvement in $Z$. officinale treated group (Day 21) when compared with values obtained for the Diabetic control group. The islets of Langerhans in the Pancreas showed considerable improvement in $\beta$ cell mass in the ginger-treated groups when compared with Diabetic control group.
\end{abstract}

\section{Introduction}

Diabetes mellitus is a group of metabolic diseases characterized by hyperglycaemia and dyslipidaemia which results from defects in both insulin secretion and/or insulin action and is a complex endocrinemetabolic and multi-factorial disorder [1].

According to the World Health Organization (1) over 422 million people around the world have diabetes. The number of people with diabetes has risen from 108 million in 1980 to 422 million in 2014 . Global prevalence of diabetes among adults over 18 years of age has risen from $4.7 \%$ in 1980 to $8.5 \%$ in 2014 . Diabetes prevalence has been rising more rapidly in middle and low-income countries. In 2012, an estimated 1.5 million deaths were directly caused by diabetes and another 2.2 million deaths were attributable to high blood glucose. More than 14 million people in the African region are diabetic and by 2040 , this figure would have doubled [2]. In the year 2015, there were more than 1.56 million cases of diabetes in Nigeria. The total adult population (20-79) afflicted with diabetes was 82,869 and 40,815 reported deaths associated with diabetes [2]. The disease is associated with reduced quality of life and increased risk factors for mortality and morbidity. Long-term hyperglycaemia is an important factor in the development and progression of micro and macro-vascular complications, which include neuropathy (diabetic neuropathy), nephropathy, cardiovascular and cerebrovascular diseases, [2].
The use of herbal medicine alongside prescription drugs for its management is quite common. Ethnobotanical surveys of plants traditionally used in diabetes management in different parts of Nigeria has been carried, [3]. The major link between the use of traditional medicine and traditional plant foods is that their uses are community-based and indigenous. Each community has its own peculiar approach to health and diseases even at the level of ethnopathological perception of diseases and therapeutic behaviours. This gives indigenous knowledge in agriculture, medicine, and health its diverse and pluralistic nature. The implication is that success for use of any indigenous plant foods that possess anti-diabetic potential when incorporated into the family diets could offer sustainable health benefits to the community/consumers of such plant foods [4].

Twenty-five indigenous diets as consumed had anti-diabetic effects. Their anti-diabetic effects were caused by their bioactive compounds. The bioactive compounds or secondary metabolites are the non-

Correspondence to: Godam Elvis Tams, Department of Human Anatomy, Faculty of Basic Medical Sciences, Bingham University Karu, Nasarawa State, Nigeria, Tel: +2348063339602; E-mail: elvisgodam@gmail.com

Key words: Z. officinale, diabetes mellitus, hippocampus, streptozotocin, neuropathy, pancrease, learning, memory and behavioural changes

Received: April 02, 2017; Accepted: May 10, 2017; Published: May 14, 2017 
Tams GE (2017) Evaluation of the neurobehavioural and Histo-architecture changes of the hippocampus and pancreas of the streptozotocin-induced diabetic male wistar rats responding to $Z$. Officinale extract

nutrient components in plant foods. These chemical compounds are found in different classes and parts of plant foods in varying amounts [5]. They are more concentrated in plant storage organs (leaves and seeds) than other parts of the plants. Z. officinale one of the 27 species of spices, condiments, grain legumes which was evaluated in this study and is believed it has potential to alleviate or improve neuropathological conditions associated with diabetes mellitus especially memory and anxiety expressed by diabetic subjects.

\section{Materials and methods}

\section{Reagents, materials and equipment}

The Reagents used were $10 \%$ formal calcium, $10 \%$ formal saline, methylated spirit, chloroform, 95\% Ethanol, streptozotocin (Sigma chemicals St. Louis, MO, USA), ALT, AST and ALP diagnostic kit (Randox-United Kingdom), Superoxide dismutase Assay kit (SOD), Glutathione Peroxidase Assay kit (GP $)$ and Malondialdehyde (MDA) (North West Life Science Specialties LLC).

The materials used are cages, plastic containers, weighing balance, standardized pellet (Vital Feeds Limited Grand cereals Jos Plateau State), tap water, distilled water, normal saline, needles, syringes, oral cannulas, gloves, lab coat, dissection kit, beakers, measuring cylinders, plain blood bottles, water bottles, reagent bottles, cotton wool, tissue paper, glass slide, coverslip, ice blocks, fridge, organ bottles, Zingiber officinale (Ginger), surgical blades, Elevated plus maze (EPM).

The equipment used were Soxhlet extraction apparatus, water bath, Laboratory kiln set at $105^{\circ} \mathrm{C}$, dryer, extraction thimbles, spectrophotometer, micropipette, centrifuge, microscope, blender, glucometer, glucometer strips.

\section{Collection and extraction of plant material}

Z. officinale was purchased from Mararaba market, Nasarawa State, Nigeria. It was chopped and shade dried. After drying, it was powdered using a blender. $1090 \mathrm{~g}$ of the powdered $Z$. officinale was extracted in 1.5 liters of $95 \%$ ethanol using a Soxhlet extractor. This was filtered using a Whatman filter paper $(24 \mathrm{~mm})$. The filtrate was dried in a laboratory water bath set at $80^{\circ} \mathrm{C}$ and total yield of $43 \mathrm{~g}$ was obtained per $1090 \mathrm{~g}$ of the powdered ginger. Extract was kept in an air tight bottle. It was reconstituted in an appropriate volume of distilled water for administration.

\section{Animal procurement}

Thirty-Five (35) male adult Wistar rats were procured from National Veterinary Research Institute (NVRI) Vom in Jos-South Local Government area of Plateau State, Nigeria.

Animal Care and Conditioning (Handling): The Wistar rats weighed between 160-180g. They were kept in well-ventilated cages cushioned with sawdust in the animal house of Bingham University, Karu, Nasarawa state, Nigeria. They were acclimatized for 2 weeks, and kept under standard conditions of room temperature $35.5-37.0^{\circ} \mathrm{C}$ and 12:12 hours light and dark cycle respectively. The Wistar rats were fed with standardized pellet (Vital Feed Limited Nyanya, Nasarawa) and tap water ad libitum. The rat cages were regularly cleaned and sawdust regularly changed (every day).

\section{Induction of experimental diabetes}

The animal models used in the test were assessed to establish their baseline blood glucose levels to ensure that all were normoglycaemic before the experiment was carried out. Type 1 diabetes was induced intraperitoneally in thirty Wistar rats which were fasted overnight prior to STZ administration. STZ was dissolved in $0.1 \mathrm{mmol} / \mathrm{l}$ sodium citrate buffer, pH 4.5, Sigma Chemical Co., St. Louis, MO, USA. The concentration of the application solution was $55 \mathrm{mg} / \mathrm{Kg} \mathrm{STZ} / 0.5 \mathrm{ml}$ sodium citrate buffer. Blood samples were collected after 72 hours after Streptozotocin injection and blood glucose level was determined using an ACCU-CHEK Glucometer. Streptozotocin-treated Wistar rats with fasting blood glucose level at $200 \mathrm{mg} / \mathrm{dl}$ and above were considered diabetic and included in the study.

\section{Experimental protocol}

Twenty male diabetic Wistar rats and five normoglycaemic male Wistar rats were randomly selected and divided into five groups of five animals each as follows: Table 1.

The crude extract of $Z$. officinale and metformin were administered once daily early in the morning $(6 \mathrm{am})$ for a period of three weeks respectively except for Group $C$ which was sacrificed on the $15^{\text {th }}$ day. The vehicle used for administering treatment was normal saline using a $2 \mathrm{ml}$ syringe and an oral cannula at the tip. Group A was given $2 \mathrm{ml}$ of normal saline for 21 days and was sacrificed on the $22^{\text {nd }}$ day. Group $\mathrm{B}$ was given $2 \mathrm{ml}$ of normal saline and was sacrificed on the $22^{\text {nd }}$ day. Group C was treated with $Z$. officinale and was sacrificed on the $15^{\text {th }}$ day. Group D was treated with $Z$. officinale and was sacrificed on the $22^{\text {nd }}$ day. Group $E$ was treated with metformin and was sacrificed on the $22^{\text {nd }}$ day. All groups were given treatment via oral intubation.

Cognitive and neurobehavioral test: On the $7^{\text {th }}$ day (training), $14^{\text {th }}$ and $21^{\text {st }}$ after diabetes confirmation, the rats were assessed for cognitive and behavioral parameters in the Elevated Plus Maze (EPM). The duration of the test was 5 minutes ( 300 seconds). The test was repeated for five days for better evaluation of learning speed in all experimental groups [6].

Anxiety test: Each Wistar rat was placed on the central platform with their heads oriented towards an Open Arm (OA). The frequency of entries into the OAs and Enclosed Arm (EAs) were scored. An arm entry is defined as all 4 paws entering an arm, and an arm exit is defined as 2 paws leaving an arm. Other parameters like grooming, urination, defecation, and rearing was also scored [6].

Learning and memory test: A line was drawn to divide the EA into 2 equal parts. On days 2 to 5 , the time it took for each rat to cross the line in the EA (transfer latency) was measured. The rat was initially placed at the end of an OA and allowed to explore for 300 seconds. The rat was required to have its body and 4 paws cross the line in the EA; if the rat did not cross the line after the time limit, transfer latency was recorded as 300 seconds.

After crossing the line, the rat was allowed to complete the time duration exploring the apparatus. Learning was defined as reduced transfer latency on day 2 compared with day 1 .

(Over the test period, experimental rats should typically cross the line in the EA more quickly on day 2 than on day 1) [6].

Table 1. Shows treatment and duration of groups.

\begin{tabular}{|l|l|c|}
\hline Groups & Treatment & Duration \\
\hline A & Normal Control+Normal Saline orally & 21 Days \\
\hline B & Diabetic Control+Normal Saline orally & 21 Days \\
\hline C & Diabetic + Z. officinale $(200 \mathrm{mg} / \mathrm{kg} \mathrm{bw})$ orally & 14 Days \\
\hline D & Diabetic + Z. officinale $(200 \mathrm{mg} / \mathrm{kg} \mathrm{bw})$ orally & 21 Days \\
\hline E & Diabetic+Metformin $(500 \mathrm{mg} / \mathrm{kg} \mathrm{bw})$ orally & 21 Days \\
\hline
\end{tabular}


Tams GE (2017) Evaluation of the neurobehavioural and Histo-architecture changes of the hippocampus and pancreas of the streptozotocin-induced diabetic male wistar rats responding to $Z$. Officinale extract

\section{Collection of blood and preparation of sera samples}

After the last treatment was given to animals, they were euthanized with chloroform-soaked in cotton wool placed in an anaesthetic box covered with lid. Blood was collected from each animal from all groups through cardiac puncture into plain sterilized centrifuge bottles and allowed to clot. The serum was separated by centrifugation at $3000 \mathrm{r}$ for 45 minutes and collected in sample bottles for determination of serum liver enzymes activities and oxidative stress markers.

Biochemical analysis: The serum that was centrifuged wasanalyzed in Department of chemical Pathology Lab, Ahmadu Bello University Teaching Hospital, Shika, Zaria spectrophotometrically for to quantify liver enzymes and oxidative stress markers.

\section{Histological analysis}

Tissue sample harvested were immersed in $10 \%$ formal calcium solution (brain) and 10\% formal saline (other tissues) in tissue bottles. Samples were then taken to the Histological Lab, Department of Anatomy, Ahmadu Bello University Zaria for preparation of slides and stained with Haematoxylin, and Eosin stain for general histological studies, and the brain tissue sample was specially stained with Bielschowsky's silver stain for neurofibrils, dendrites, and axons in paraffin and frozen sections, modified method $[7,8]$.

\section{Statistical analysis}

All of the data are expressed as mean \pm SD. Statistical significance between more than two groups was tested using one-way ANOVA followed by the Duncan's post hoc test as appropriate using a computerbased fitting program (SPSS/15). Differences were considered to be statistically significant when $\mathrm{P}<0.05$.

\section{Results}

\section{Morphological results (Table 2)}

\section{Blood glucose result (Table 3 and 4)}

\section{Behavioural performance (Table 5 and 6)}

\section{Histological results}

\section{Pancreas}

The normal control group (Figure 1) shows normal pancreatic islets $\beta$ cell of Langerhans and no observable pancreatic damage. Diabetic control group (Figure 2) shows necrotic damage to the pancreatic islet $\beta$ cells. Z. officinale Diabetic treated group (Day 14) (Figure 3) shows restoration of pancreatic islet $\beta$ cells. $Z$. officinale Diabetic treated group (Day 21) (Figure 4) shows restoration of pancreatic islet $\beta$ cells while Metformin treated diabetic group (Figure 5) shows degenerated pancreatic $\beta$ cells.

Table 2. Mean body weight ( $\mathrm{g}$ ) of Wistar rats.

\begin{tabular}{|c|c|c|c|c|}
\hline Groups(n=5) & Day 1 & Day 7 & Day 14 & Day 21 \\
\hline A & $173.20 \pm 5.06$ & $186.60 \pm 6.34$ & $205.20 \pm 8.16$ & $218.60 \pm 7.26$ \\
\hline B & $170.80 \pm 6.61$ & $149.20 \pm 5.06^{\mathrm{d}}$ & $138.60 \pm 8.01^{\mathrm{d}}$ & $125.80 \pm 5.89^{\mathrm{d}}$ \\
\hline C & $166.80 \pm 6.76$ & $139.00 \pm 7.84^{\mathrm{cd}}$ & $158.00 \pm 3.39^{\mathrm{c}}$ & - \\
\hline D & $171.80 \pm 4.96$ & $148.20 \pm 6.05^{\mathrm{d}}$ & $162.40 \pm 7.73^{\mathrm{b}}$ & $171.40 \pm 2.60^{\mathrm{b}}$ \\
\hline E & $169.00 \pm 5.65$ & $148.20 \pm 4.14^{\mathrm{d}}$ & $168.00 \pm 5.78^{\mathrm{b}}$ & $168.00 \pm 5.78^{\mathrm{c}}$ \\
\hline
\end{tabular}

Values expressed as mean \pm standard deviation (SD) of the weight of Wistar rats during the experiment in grams. Values with superscript in a column are significantly different ( $p<$ 0.05) A: Normal Control; B: Diabetic Control; C: Diabetes $+Z$. officinale (14); D: Diabetes $+Z$. officinale (21); E: Diabetes+Metformin. Different alphabets show level of significance.
Table 3. Mean blood glucose level (mg/dl).

\begin{tabular}{|c|c|c|c|c|}
\hline Groups(n=5) & Day 1 & Day 7 & Day 14 & Day 21 \\
\hline A & $68.40 \pm 5.81$ & $68.60 \pm 4.82$ & $73.40 \pm 6.73$ & $73.80 \pm 4.08$ \\
\hline B & $305.60 \pm 118.09^{\mathrm{b}}$ & $322.80 \pm 16.20^{\mathrm{c}}$ & $442.60 \pm 19.85^{\mathrm{d}}$ & $518.60 \pm 24.43^{\mathrm{d}}$ \\
\hline C & $366.40 \pm 47.72^{\mathrm{c}}$ & $328.40 \pm 49.26^{\mathrm{c}}$ & $230.20 \pm 21.28^{\mathrm{b}}$ & - \\
\hline D & $451.60 \pm 37.62^{\mathrm{d}}$ & $403.00 \pm 38.41^{\mathrm{d}}$ & $351.40 \pm 27.29^{\mathrm{c}}$ & $264.00 \pm 34.61^{\mathrm{b}}$ \\
\hline E & $408.80 \pm 27.99^{\mathrm{d}}$ & $271.80 \pm 15.91^{\mathrm{b}}$ & $235.40 \pm 11.71^{\mathrm{b}}$ & $208.40 \pm 11.30^{\mathrm{b}}$ \\
\hline
\end{tabular}

Values expressed as mean $\pm \mathrm{SD}$ of the Blood glucose level $(\mathrm{mg} / \mathrm{dl})$ of Wistar rats during the experiment in grams. Values with superscript in a column are significantly different $(\mathrm{p}<0.05)$. A: Normal Control; B: Diabetic Control; C: Diabetes + Z. officinale (14); D: Diabetes $+Z$. officinale (21); E: Diabetes + Metformin. Different alphabets show level of significance.

Table 4. Mean values of Malondialdehyde (MDA), Glutathione peroxidase (GPx) and Superoxide dismutase (SOD)

\begin{tabular}{|c|c|c|c|}
\hline Groups (n=5) & $\begin{array}{c}\text { MDA } \\
(\mathbf{n m o l s} / \mathbf{m g} \text { protein) }\end{array}$ & $\begin{array}{c}\mathbf{G P x} \\
(\boldsymbol{\mu} \mathbf{g} / \mathbf{m l})\end{array}$ & $\begin{array}{c}\text { SOD } \\
(\mathbf{U} / \mathbf{m l})\end{array}$ \\
\hline A & $478.28 \pm 23.87$ & $66.18 \pm 2.29$ & $29.10 \pm 1.43$ \\
\hline B & $949.44 \pm 30.62^{\mathrm{d}}$ & $29.82 \pm 1.03^{\mathrm{d}}$ & $15.12 \pm 0.78^{\mathrm{d}}$ \\
\hline C & $679.32 \pm 11.58^{\mathrm{c}}$ & $58.42 \pm 0.71^{\mathrm{bc}}$ & $22.10 \pm 5.88^{\mathrm{bc}}$ \\
\hline D & $560.38 \pm 19.17^{\mathrm{b}}$ & $66.11 \pm 2.80^{\mathrm{a}}$ & $28.64 \pm 1.30^{\mathrm{b}}$ \\
\hline E & $667.52 \pm 11.41^{\mathrm{bc}}$ & $44.03 \pm 6.44^{\mathrm{c}}$ & $26.86 \pm 1.65^{\mathrm{bc}}$ \\
\hline
\end{tabular}

Values expressed as mean \pm SD of the free radicals and antioxidants of Wistar rats. Values with superscript in a column are significantly different $(\mathrm{p}<0.05)$. Different alphabets show level of significance. A: Normal Control; B: Diabetic Control; C: Diabetes $+Z$. officinale (14); D: Diabetes $+Z$. officinale (21); E: Diabetes + Metformin. MDA: Malondialdehyde; GPx: Glutathione Peroxidase; SOD: Superoxidase Dismutase

Table 5. Mean values of Grooming, rearing, defecation, urination, CAE and OAE.

\begin{tabular}{|c|c|c|c|c|c|c|}
\hline Groups & Grooming & Rearing & Defecation & Urination & CAE & OAE \\
\hline A & $4.64 \pm 0.65$ & $6.08 \pm 1.47$ & $0.32 \pm 0.17$ & 0.00 & $1.92 \pm 0.75$ & $0.56 \pm 0.51$ \\
\hline B & $3.72 \pm 1.46^{\mathrm{c}}$ & $2.84 \pm 1.30^{\mathrm{c}}$ & $2.84 \pm 0.79^{\mathrm{d}}$ & $1.00 \pm 0.46^{\mathrm{d}}$ & $0.28 \pm 0.17^{\mathrm{d}}$ & $0.00^{\mathrm{d}}$ \\
\hline C & $2.90 \pm 1.63^{\mathrm{b}}$ & $0.80 \pm 0.44^{\mathrm{d}}$ & $2.30 \pm 1.44^{\mathrm{c}}$ & $0.00^{\mathrm{a}}$ & $0.70 \pm 0.44^{\mathrm{c}}$ & $0.00^{\mathrm{d}}$ \\
\hline D & $4.96 \pm 1.32^{\mathrm{a}}$ & $4.20 \pm 1.97^{\mathrm{bc}}$ & $0.76 \pm 0.26^{\mathrm{b}}$ & $0.36 \pm 0.16^{\mathrm{ab}}$ & $1.20 \pm 0.66^{\mathrm{b}}$ & $0.00^{\mathrm{d}}$ \\
\hline E & $1.88 \pm 0.41^{\mathrm{d}}$ & $3.72 \pm 0.48^{\mathrm{bc}}$ & $1.16 \pm 0.49^{\mathrm{bc}}$ & $0.24 \pm 0.16^{\mathrm{ab}}$ & $1.16 \pm 0.16^{\text {bc }}$ & $0.44 \pm 0.21^{\mathrm{b}}$ \\
\hline
\end{tabular}

Values expressed as mean \pm SD of the behavioural parameters of Wistar rats. Values with superscript in a column are significantly different $(\mathrm{p}<0.05)$. Different alphabets show level of significance. A: Normal Control; B: Diabetic Control; C: Diabetes $+Z$. officinale (14); D: Diabetes + Z. officinale (21); E: Diabetes + Metformin. CAE: Closed arm entry; OAE: Open arm entry.

Table 6. Mean values of Transfer Latency.

\begin{tabular}{|c|c|c|c|c|}
\hline Groups (n=5) & \multicolumn{4}{|c|}{ Transfer Latency (Seconds) } \\
\hline & Day 1 & Day 2 & Day 3 & Day4 \\
\hline A & $12.00 \pm 4.52$ & $14.20 \pm 6.01$ & $9.20 \pm 3.11$ & $10.40 \pm 1.51$ \\
\hline B & $248.80 \pm 114.48^{\mathrm{d}}$ & $249.60 \pm 112.69^{\mathrm{d}}$ & $253.60 \pm 103.75^{\mathrm{d}}$ & $255.60 \pm 99.28^{\mathrm{d}}$ \\
\hline C & $165.80 \pm 122.51^{\mathrm{c}}$ & $137.20 \pm 102.52^{\mathrm{c}}$ & $127.60 \pm 100.82^{\mathrm{c}}$ & $104.80 \pm 86.09^{\mathrm{c}}$ \\
\hline D & $119.80 \pm 100.80^{\mathrm{b}}$ & $113.60 \pm 104.21^{\mathrm{bc}}$ & $103.80 \pm 109.71^{\mathrm{bc}}$ & $80.20 \pm 122.92^{\mathrm{bc}}$ \\
\hline E & $240.40 \pm 54.96^{\mathrm{bc}}$ & $83.00 \pm 1.58^{\mathrm{b}}$ & $44.20 \pm 1.92^{\mathrm{b}}$ & $18.20 \pm 0.83^{\mathrm{b}}$ \\
\hline
\end{tabular}

Values expressed as mean \pm SD of the transfer latency of Wistar rats. Values with different superscript in a column are significantly different $(\mathrm{p}<0.05)$. Different alphabets show level of significance. A: Normal Control; B: Diabetic Control; C: Diabetes $+Z$. officinale (200mg/kgbw) (14); D: Diabetes + Z. officinale (200 mg/kgbw) day 21; E: Diabetes + Metformin (500 mg/kgbw).

\section{Hippocampus}

Haematoxylin and Eosin: The Normal control group (Figure 6) shows normal neuronal cells with distinctive cell layers, Diabetic control group (Figure 7) shows increased pericellular spaces and chromatolysis signifying neuronal cell damage or neurodegeneration, $Z$. officinale treated diabetic group (Day 14) (Figure 8) shows restoration of neuronal cells with distinctive characteristic cell layers, $Z$. officinale treated diabetic group (Day 21) (Figure 9) shows restoration of neuronal cells with neuronal cell and layers and Metformin treated 
Tams GE (2017) Evaluation of the neurobehavioural and Histo-architecture changes of the hippocampus and pancreas of the streptozotocin-induced diabetic male wistar rats responding to $Z$. Officinale extract

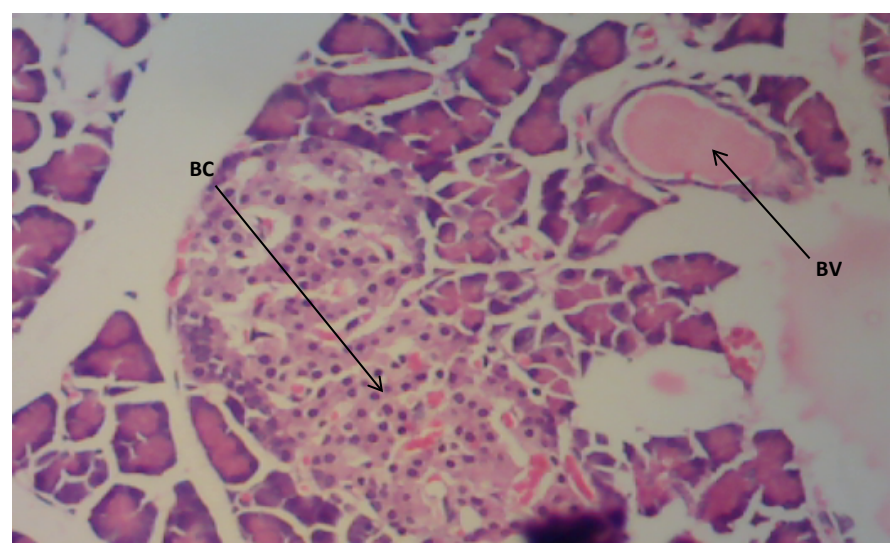

Figure 1. Photomicrograph of Pancreatic sections of Group A, normal pancreatic $\beta$ cells (BC) and blood vessels (BV). (H\&E) X100.

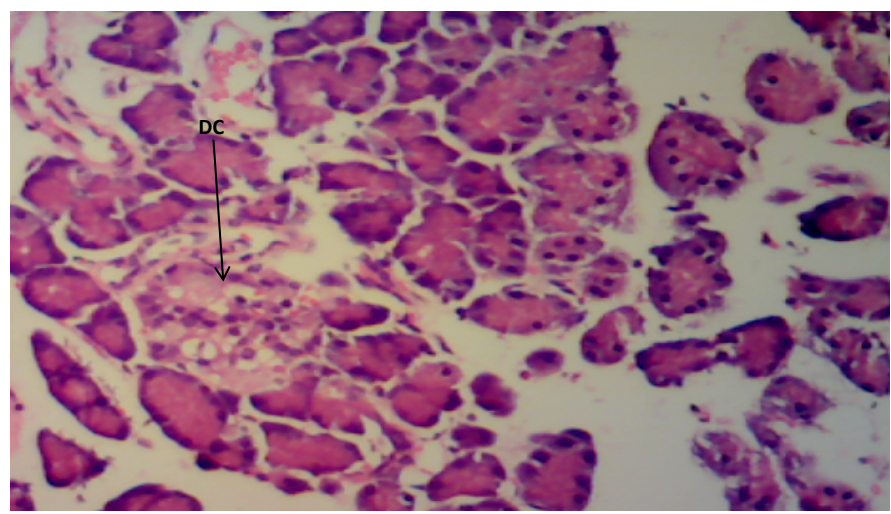

Figure 2. Photomicrograph of Pancreas section of Group B, destroyed pancreatic $\beta$ cells (DC). (H\&E) X100.

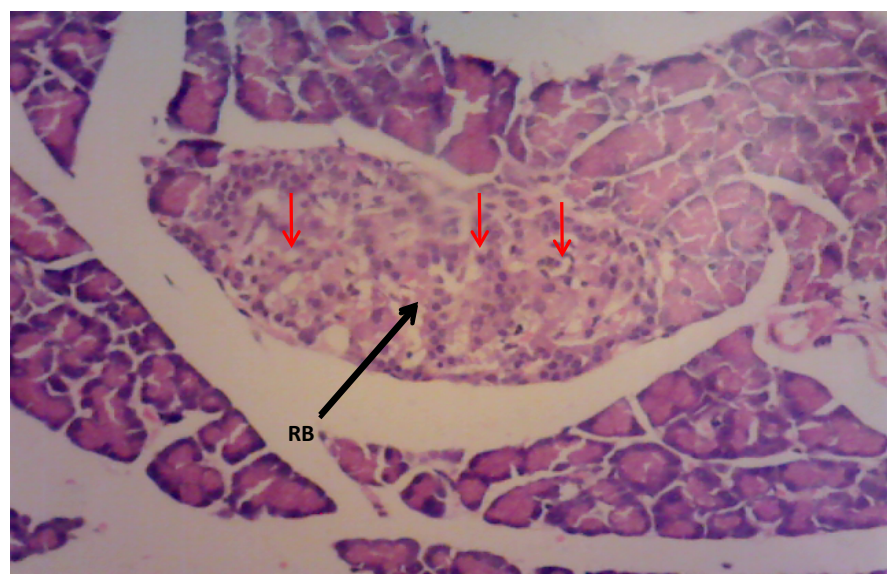

Figure 3. Photomicrograph of Pancreas section of Group $C$, restored pancreatic $\beta$ cell mass (RB) with marked cytoplasmic vacuolation, (H\&E) X100.

diabetic group (Figure 10) shows partial restoration of neuronal cells cell layers [7].

Bielschowskys silver stain: The Diabetic control group (Figure 11) shows distorted cell layer and degenerated pyramidal cells, Z. officinale treated diabetic group (Day 14) (Figure 12) shows distinctive cell layer and preserved pyramidal cells, $Z$. officinale treated diabetic group (Day 21) (Figure 13) shows distinctive cell layer and more preserved pyramidal cells, Metformin treated diabetic group (Figure 14) shows degenerated pyramidal cells and distorted cell layer [8].

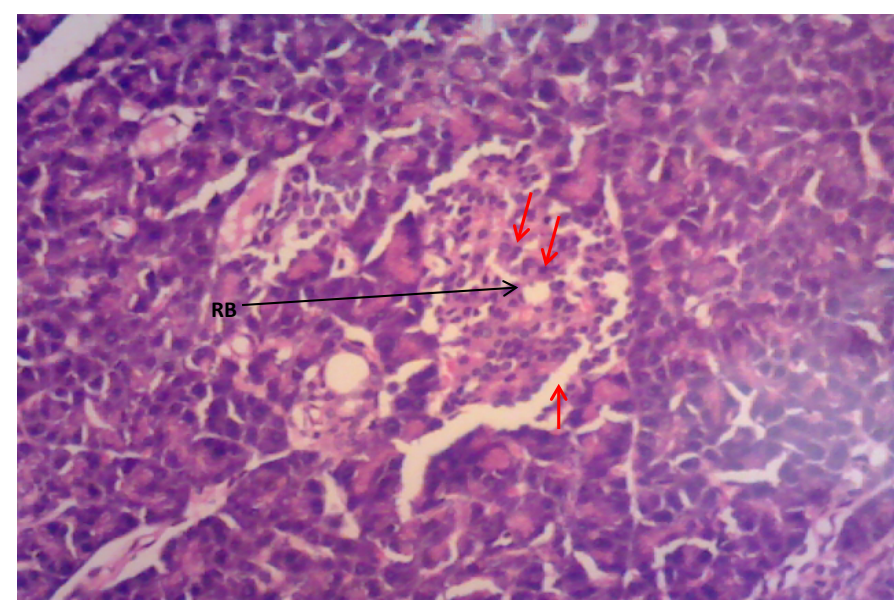

Figure 4. Photomicrograph of Pancreas section of Group D. There is restoration of pancreatic $\beta$ cell mass (RB). (H\&E) X100.

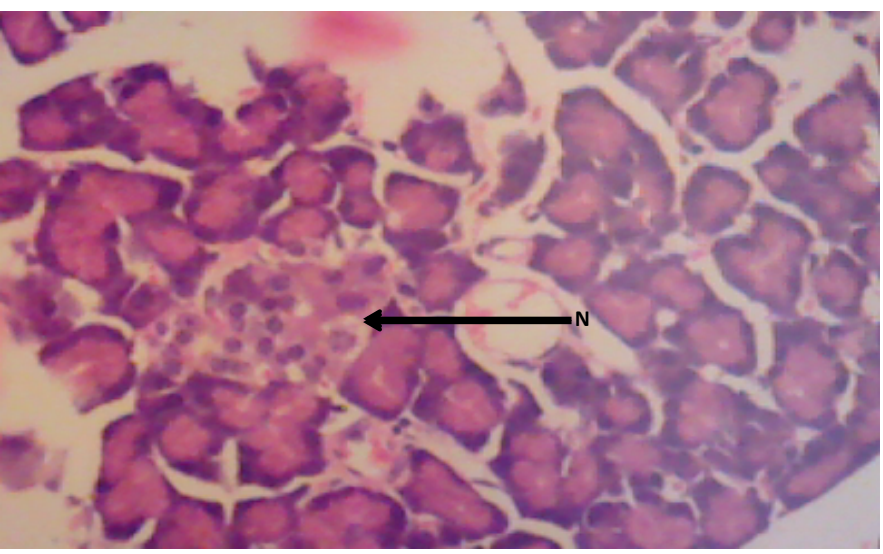

Figure 5. Photomicrograph of Pancreas section of Group E. Necrotic pancreatic $\beta$ cell mass (N) (H\&E) X100.

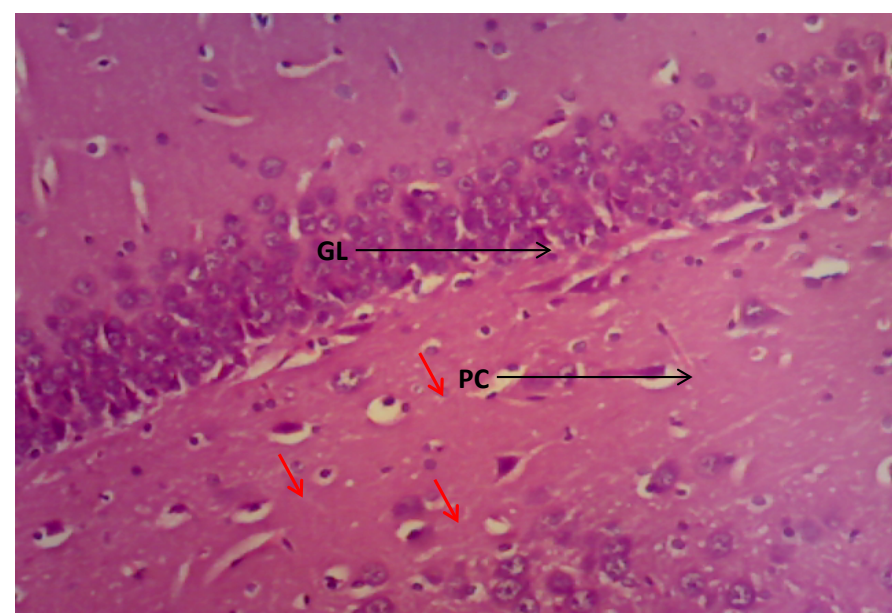

Figure 6. Photomicrograph of the hippocampus of Group A, granular cell layer (GL) and normal pyramidal cell (PC). (H\&E) X100.

\section{Discussions}

\section{Histology studies}

Pancreas: The Pancreas is a mixed exocrine and endocrine gland. The $\beta$ cells in the endocrine pancreas are responsible for the production of insulin which keeps the body glucose level in a normoglycaemic 
Tams GE (2017) Evaluation of the neurobehavioural and Histo-architecture changes of the hippocampus and pancreas of the streptozotocin-induced diabetic male wistar rats responding to $Z$. Officinale extract

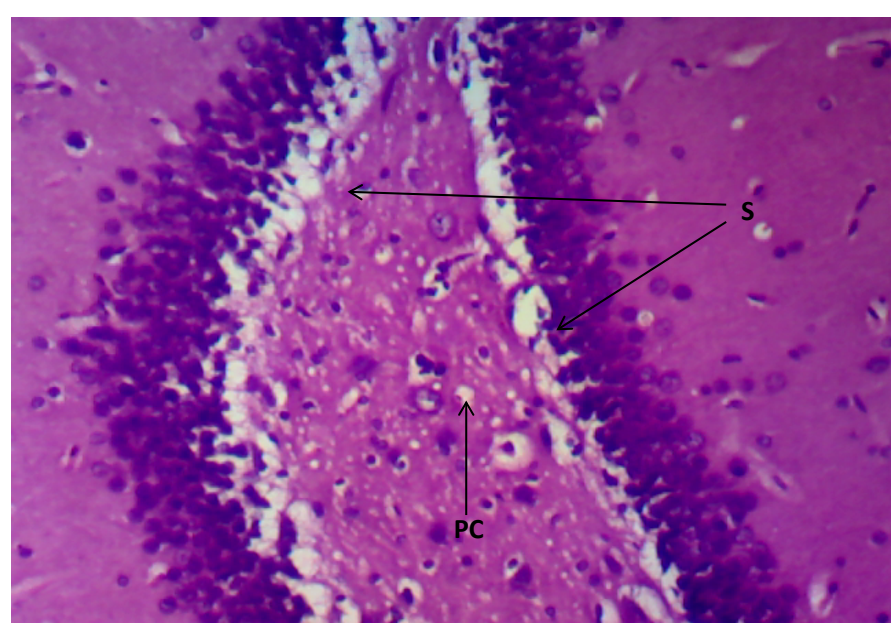

Figure 7. Photomicrograph of the hippocampus of Group B, a degenerated pyramidal cell (PC), and reduced neuronal cell layer (S). (H\&E) X100.

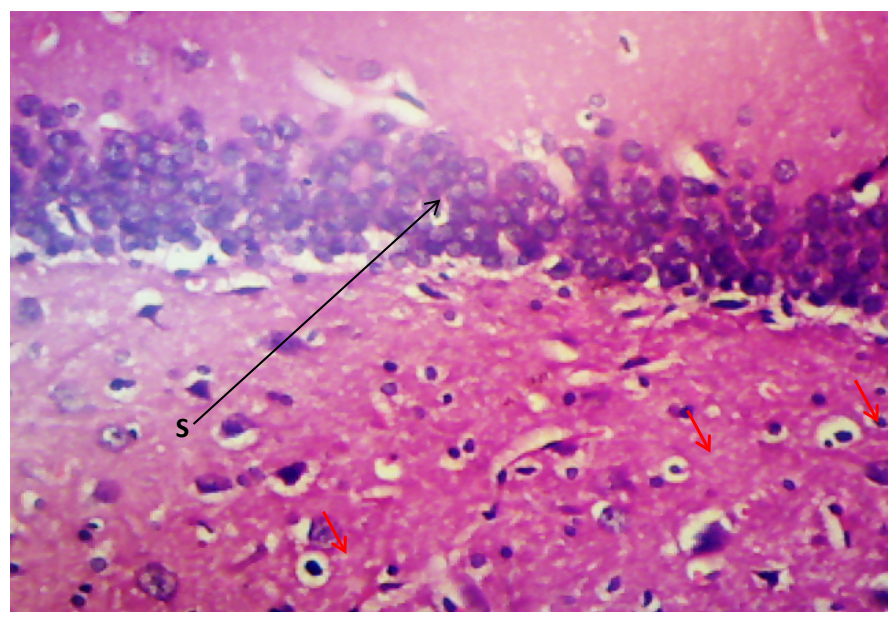

Figure 8. Photomicrograph of the hippocampus of Group C, preserved cell layer (S). (H\&E) X100.

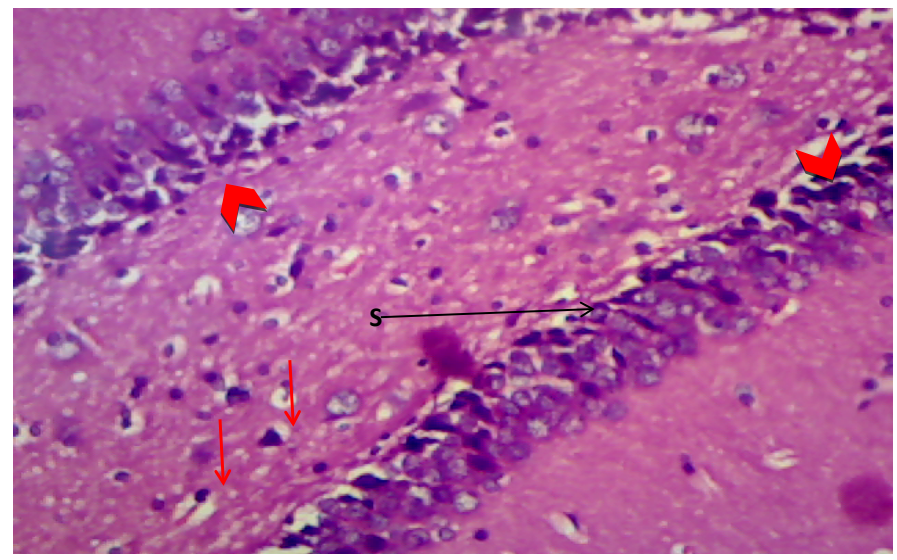

Figure 9. Photomicrograph of the hippocampus of Group D, showing preserved neuronal cell layer (S). (H\&E) X100.

state. When blood glucose is high, insulin is secreted from the $\beta$ cells which help the cells to utilize the glucose in the blood. STZ is used for the induction of T1DM because its toxicity is specific to the $\beta$ cells in the endocrine pancreas. It destroys the $\beta$ cells causing no secretion or a reduction in the secretion of insulin. The pancreas from the normal control group Figure 1) shows normal pancreatic islet cell mass with normal $\beta$ cells which explains normoglycemia in the normal control (A), figure 2 for Group B shows necrosis of the pancreatic islet cells and a complete reduction of the $\beta$ cells which explains the extremely high blood glucose level in the diabetic group (B). Figure 3 shows the restoration of the pancreatic islet cells and a normal $\beta$ cell mass and there was a regeneration of the pancreatic islet cells in Figure 4. Figures 3 and 4 are diabetic groups treated with $Z$. officinale which explains the gradual decrease in the blood glucose level in those groups and this was

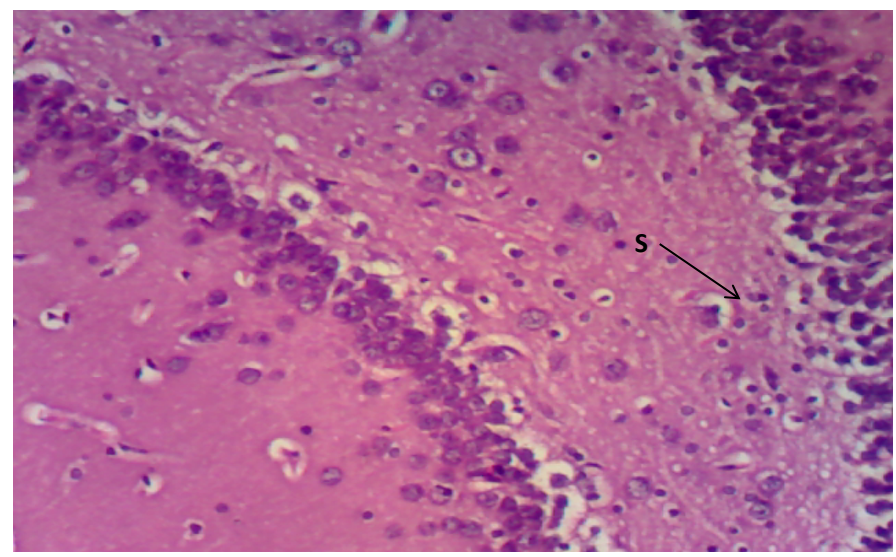

Figure 10. Photomicrograph of the hippocampus of Group E, more pericellular spaces indicating cell damage (S). (H\&E) X100.

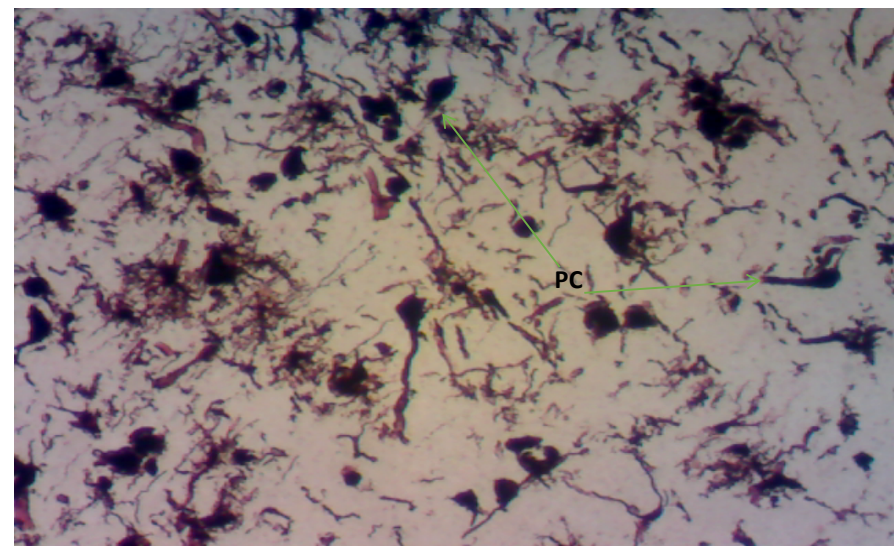

Figure 11. Photomicrograph of the hippocampus of Group B showing degenerated pyramidal cells (PC). Bielchowsky Silver stain X100.

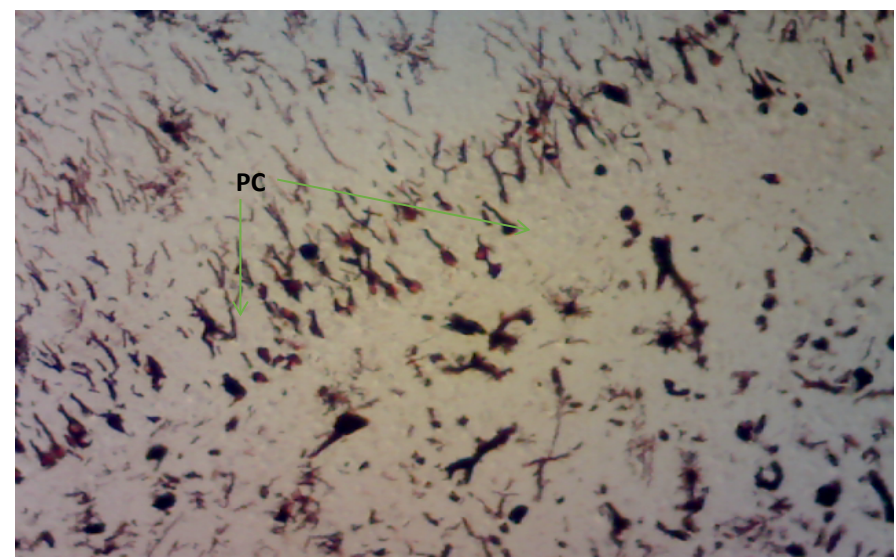

Figure 12. Photomicrograph of the hippocampus of Group $\mathrm{C}$ demonstrating preserved pyramidal cells (PC). Bielschoskys Silver stain X100. 


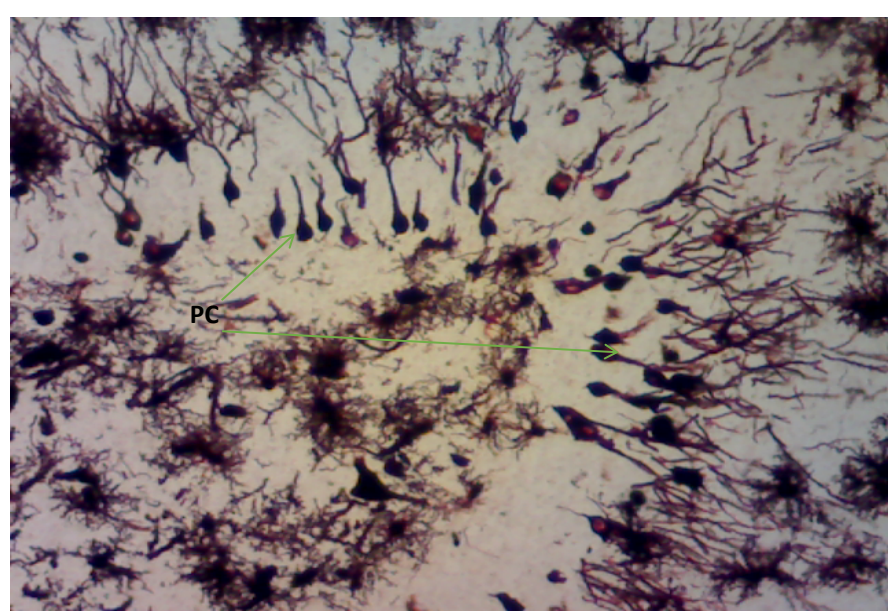

Figure 13. Photomicrograph of the hippocampus of Group D showing more preserved pyramidal cells (PC). Bielchowskys Silver stain X100.

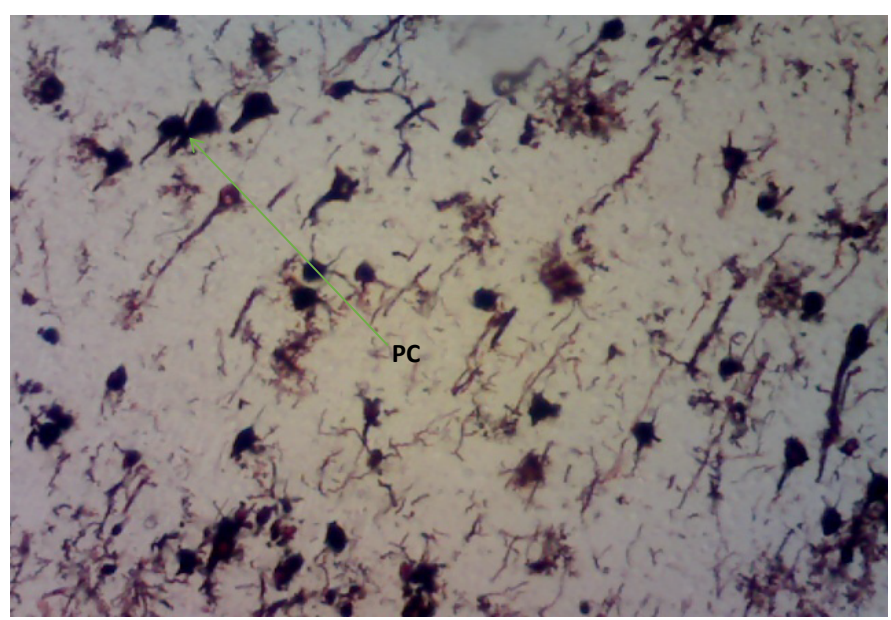

Figure 14. Photomicrograph of the hippocampus of Group E. Degenerated pyramidal cells and distortion of the cell layer (PC). Bielschoskys Silver stain X100.

in agreement with who revealed that ginger was shown to modulate insulin release in rats pancreatic $\beta$-cells which was due to its active component 6-gingerol [6]. The gradual reduction caused the gradual increase in the weight also because they were able to gradually utilize the glucose in the blood. Figure 5 shows the complete destruction of the $\beta$ cells in the pancreatic islet cells. Z. officinale had regenerative effects on the pancreas because there was restoration of the $\beta$ cells in the diabetic group treated with it.

Hippocampus: The hippocampus forms part of the limbic system and functions majorly in long-term memory and spatial navigation. Damage in any cell in the hippocampus can cause gross effects on the learning process of the individual. Astrocytes are most numerous glial cells in the brain and they help in the filling of spaces forming glial scars caused by neuronal damage and also help to repair the damaged cells that cannot be regenerated and a reduction in the number of these glial cells that help keep neuronal cells connected will cause a deficit in cell to cell connection. Figure 16 shows the normal hippocampus showing the different cell layers with no neuronal injury which is in support with the biochemical findings on free radicals and antioxidants. Figure 7 (Diabetic control) as compared to figure 6 (normal control) shows neuronal injury which was prominent throughout the granular layer which is in support with the biochemical analysis done on free radicals and antioxidants which shows elevated levels of free radicals and reduced levels of antioxidants proving low defence against free radicals which caused an increase in neurodegeneration and this was evident in the behavioural study. Diabetic control (Figure 11) shows degenerated pyramidal cells with short and disconnected processes and also has very few astrocytes with pericidal spaces. Figure 12 and figure 13 (Diabetes+Z. officinale 14 and day 21) showed well preserved pyramidal cells in both groups. Figure 13 shows preserved neuronal cells as compared to that of figure 11, the astrocytes seen in figure 12 were numerous compared to that of the other groups which confirms the neuroprotective effect of $Z$. Officinale on brain cell and this finding is in agreement with, which observed that the administration of $Z$. officinale to diabetic rats increased astroglial response to injury which improved neurogenesis [9].

Behavioural performance: The EPM is a widely-accepted test in the study of anxiety in rodents and other animal models and is also sensitive enough to detect deficits in associative learning and memory in rats. The EPM test is based on the spontaneous exploratory behaviour of rodents, and their natural aversion to the open arms caused by fear and anxiety (6). The EPM test reveals increased anxiety in diabetic control group compared to the normal control and the diabetic Ginger treated groups. The entry into the open arm was significantly different in the diabetic group when compared to the normal control. The frequency of grooming between normal control and diabetic group was significantly different at $(\mathrm{P}<0.05)$ and was significantly different $(\mathrm{P}<0.05)$ with the other parameters. The entry into the enclosed arm of the diabetic groups was significantly different $(\mathrm{P}<0.05)$ with the control group. The frequency of defecation observed in the diabetic control (B) and Z. officinale treated group (C) was significantly different from the normal control with significant values $(\mathrm{P}<0.05)$ showing positive reduction in cognitive impairment because of reduced frequency of defecation, anxiety, increased grooming behavioural activities in $Z$. officinale treated group (D).

Learning and memory in the EPM test are defined as Transfer Latency which is the time it takes the rat to leave the open arm to cross the line dividing the enclosed arm on the second day. The learning speed is observed as the time it took the Wistar rat to go to the enclosed arm on the second day which is supposed to decrease after the first day. Subsequently, the Transfer Latency is supposed to reduce. The EPM learning and memory measures from Day 2 to Day 5 trials reveals that the diabetic control group differed significantly $(\mathrm{P}<0.05)$ from diabetic Ginger treated group (D.) The Metformin treated group (E) was not significant when comparing with Group $\mathrm{D}(\mathrm{P}<0.05)$. The learning process and memory of the $Z$. officinale treated diabetic group (D) was not comparable with that of the normal control but show significant similarities with the Metformin treated group. The $Z$. officinale treated diabetic group $(C)$ was significantly different from the normal control on Day 2 to 5. Z. officinale treated diabetic group (D) was not significantly different $(\mathrm{P}<0.05)$ from the Metformin treated group (E). The new findings of this study showed that $Z$. officinale treatment improved the learning process and memory of the Diabetic Wistar rats when compared to the diabetic control and had the same cognitive speed with that of the normal control group.

\section{Conclusion}

From this study Z. officinale helped in the retaining the weights of the diabetic treated Wistar rats when compared with that of the diabetic control group and increased intracellular antioxidants which helped in the mopping out of free radicals that causes damage to the 
Tams GE (2017) Evaluation of the neurobehavioural and Histo-architecture changes of the hippocampus and pancreas of the streptozotocin-induced diabetic male wistar rats responding to $Z$. Officinale extract

neuronal cells and pancreatic islet $\beta$ cells thereby improving $\beta$ cells mass in the islets of Langerhans and neuronal cells in the hippocampus in Z. officinale treated groups (day 14 and day 21) as compared to the group treated with the standard drug.

\section{References}

1. WHO Report of a WHO Consultation Part 1(1999) Diagnosis and Classification of Diabetes Mellitus. pp. 2-3.

2. International Diabetes Federation (IDF) (2015) Diabetes atlas, $7^{\text {th }}$ (edn) Brussels, Belgium.

3. Soladoye MO, Chukwuma EC, Owa FP (2012) An 'Avalanche' of plant species for the traditional cure of diabetes mellitus in South-Western Nigeria. J Nat Prod Plant Resour 2: 60-72.

4. Udenta EA, Obizoba IC, Oguntibeju OO (2014). Anti-Diabetic Effects of Nigerian
Indigenous Plant Foods/Diets. Antioxidant-Antidiabetic Agents and Human Health, pp: 70-83.

5. Pellow S, Chopin P, File SE, Briley M (1985) Validation of open:closed arm entrie in an elevated plus-maze as a measure of anxiety in the rat. J Neurosci Methods 14 : 149-167. [Crossref]

6. Aggarwal BB (2010) Targeting inflammation-induced obesity and metabolic diseases by curcumin and other nutraceuticals. Annu Rev Nutr 30:173-199. [Crossref]

7. Bancroft DJ, Gamble M (2008) Haematoxylin and Eosin staining method (Mayers 1903). Theory and Practice of Histological technique, $6^{\text {th }}(\mathrm{edn}), 123-127$.

8. Bancroft, DJ and Gamble M, (2008) Bielschowsky's silver stain for neurofibrils, dendrites, and axons in paraffin and frozen sections, modified (Chan \& Lowe 2002). Theory and practice of Histological technique, $6^{\text {th }}(\mathrm{edn}), 369-371$.

9. El-Akabawy G, El-Kholy W (2014) Neuroprotective effect of ginger in the brain of streptozotocin-induced diabetic rats. Ann Anat 196: 119-128. [Crossref]

Copyright: $\mathbb{0} 2017$ Tams GE. This is an open-access article distributed under the terms of the Creative Commons Attribution License, which permits unrestricted use, distribution, and reproduction in any medium, provided the original author and source are credited. 